\title{
DIVERSITY AND DISTRIBUTION OF DIATOMS IN BAGMATI RIVER, KATHMANDU, NEPAL
}

\author{
Shiva Kumar Rai* and Sudip Khadka \\ Phycology Research Lab, Department of Botany, Post Graduate Campus \\ Tribhuvan University, Biratnagar, Nepal \\ *E-mail: sk.khaling@gmail.com
}

\begin{abstract}
Diversity and distribution of diatoms in different seasons from different localities and habitats of Bagmati River, Kathmandu was studied. Samples were collected as epilithic forms using a toothbrush, epipelic forms using a dropper, and epiphytic forms by squeezing aquatic macrophytes and were preserved in FAA solution. The dominant diatom taxa of Bagmati river were Achnanthes crenulata, Gomphonema pseudoaugur, Nitzschia linearis, N. palea, Pinnularia cf divergens and Surirella linearis. Out of 48 taxa reported, maximum taxa (87.5\%) were found at Mulkharka site whereas taxa were minimum (39.58\%) at Pashupati-Guheshwori site. The sizes of diatom cell, from largest to smallest, also followed the same pattern as above. Ten diatom taxa were common in all three sites. Seasonal and habitat diversity of diatom studied in Mulkharka site showed that the maximum number of taxa was reported during summer $(92.85 \%)$ and least during winter $(23.8 \%)$, and maximum taxa were found as epilithic (85.71\%) followed by epipelic (38.09\%) and epiphytic (33.33\%).
\end{abstract}

Key words: Algae, bacillariophyceae, epilithic, pashupati temple, seasonal variation

\section{INTRODUCTION}

Diatoms (Bacillariophyceae) are the unique algae as their cell wall (frustule) is made up of two overlapping pieces of silica. They are microscopic, unicellular (sometimes colonial and filamentous), aflagellated, uninucleated, diploid organisms with generally two major types of morphological shapes i.e., centric (valve circular) and pinnate (valve elongated). Chloroplast contains chlorophyll-c and chlorophyll-a, together with fucoxanthin, diatoxanthin, and diadinoxanthin pigments. Reserved foods are oil and chrysolaminarin but never starch. Reproduction is primarily by binary fission, sometimes by statospores (cysts or endospores), auxospores, and uni- or bi-flagellate microspores. In binary fission, one daughter cell receives larger frustules (or epitheca) and another daughter cell receives small frustules (or hypotheca) from the parent cell. Vegetative cells also divide by meiosis, producing male and female gametes which then fuse to form a zygote. In centric diatoms, small male gametes have one flagellum while female gametes are large and non-motile. In pennate diatoms, both the gametes lack flagella (isogamous) (Grethe et al., 1996). The zygote sheds its silica theca and grows into a large spherical auxospore. A new diatom cell of the maximum size, as the initial cell, forms within the auxospore thus beginning a new generation. Diatoms are distributed in all short of aquatic habitats throughout the world. All diatom species are not cosmopolitan in distribution. Though there are many species with global distributions, a significant number of species have distinct regional or local distributions; particularly in the polar Antarctic region and ancient lakes 
(Vyverman et al., 2010). The endemic species of diatom of Nepal is Gomphonema turris var. nepalensis Hirano (Baral, 1999). The number of diatoms species described in the world is between 25,000 and 30,000; in India is around 14,700 taxa (Karthick et al., 2013); and in Nepal is 192 species (Baral, 1999).

The work on diatom flora of Nepal is still at an early stage. Sporadic records have been made by some foreign workers from different places along the route during their different expeditions to the Himalaya regions. Carter (1926) has reported Navicula confervacea from Makawanpur district which seems to be the first record of diatom from Nepal. A significant contribution was made by Hirano (1955) reporting 69 diatom species from Phewa lake, Kaski; Ankhu khola and Luitel bhanjyang, Gorkha; Tandi khola, Pisang and Thaple Himal, Manang; and Kali Gandaki and Tukuche moor, Mustang. Later on, contribution on diatom of Nepal was made by various workers (Hirano, 1969, 1984; Suxena and Venkateswarlu, 1968; Nakanishi, 1986; Aryal and Lacoul, 1996; Jüttner et al., 1996, 2003, 2010, 2011; Habib, 1997; Cantonati et al., 2001; Van de Vijver, 2011; Krstić et al., 2012, 2013).

Diatoms of Kathmandu valley was studied by Hirano (1963) and Hickel (1973). Few species of diatoms have been reported from Sundarijal, Bagmati River (Shrestha and Manandhar, 1983; Simkhada and Jüttner, 2006). The literature on diatoms of Bagmati river is least available. Thus, the present work aimed to study the diversity and distribution of diatoms at three localities of Bagamati river in three different seasons.

\section{MATERIALS AND METHODS}

\section{Study sites}

The Bagmati is a holly river, originated from Baghdwar, south of Shivapuri Hills and flows through Pashupatinath Temple, Kathmandu valley and leaves the valley at Chobhar. The climate of Kathmandu valley ranges from subtropical $(88.2 \%$ area lies in 1,000 to 2,000 $\mathrm{m}$ asl) to temperate $(11.8 \%$ area lies in 2,000 to $3,000 \mathrm{~m}$ asl). The average annual temperature and precipitation of Kathmandu are $18.3^{\circ} \mathrm{C}$ and $1343 \mathrm{~mm}$, respectively.

Three diatom sampling sites were selected along the Bagmati river viz., site 1- Mulkharka (above Sundarijal), site 2- Gokarna, and site 3Pashupati-Guheshwori (Fig. 1).

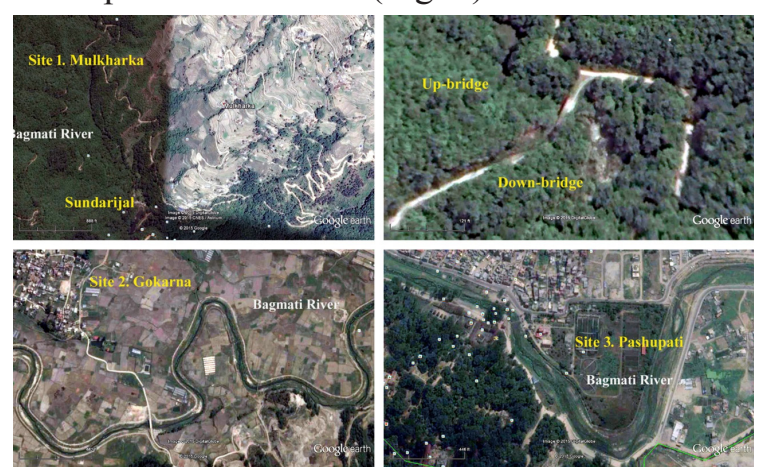

Fig. 1. Diatom collection sites along the Bagmati River: Mulkharka, Gokarna and Pashupati.

Site 1: Mulkharka lies about $1 \mathrm{~km}$ north from Sundarijal Water Reservoir, in Sundarijal Gokarneshwor Municipality (Shivapuri Nagarjun National Park), on the north western corner of Kathmandu. The river is surrounded by a dense forest of Castonopsis and Schima. This site was further divided into two parts; "up bridge" (27 $46^{\prime} 45.02^{\prime \prime N}, 8^{\circ} 25^{\prime} 27.37^{\prime \prime E}$, alt. $1674 \mathrm{~m}$ asl) and "down bridge" (27\%46'44.19"N, $85^{\circ} 25^{\prime} 29.09^{\prime \prime E}$, alt. $1662 \mathrm{~m}$ asl). This site was assumed to be the fresh and unpolluted site because there was no human disturbance observed around the area. The diatom sample collection of three seasons viz., summer, rainy and winter was made from this site.

Site 2: Gokarna $\left(27^{\circ} 44^{\prime} 6.64^{\prime \prime} \mathrm{N}, 8^{\circ} 24^{\prime} 17.83^{\prime \prime} \mathrm{E}\right.$, alt. $1325 \mathrm{~m}$ asl) lies in Sundarijal Gokarneshwor Municipality where the river just enters into the 
plain valley. The river is narrow, channel like, with slow running water. This site was taken as mildly polluted site as this is the semi urbanized area and human disturbance on the river area could be seen. Sample collection of the only rainy season was done in this site.

Site 3: Pashupati-Guheshwori $\left(27^{\circ} 42^{\prime} 37.43^{\prime \prime N}\right.$, $85^{\circ} 21^{\prime} 15.99^{\prime \prime} \mathrm{E}$, alt. $1306 \mathrm{~m}$ asl) area lies in Kathmandu Metropolitan City. It is the most important religious place for Hindus. This site lies at the centre of the Kathmandu city and surrounded by dense urbanization. This site was taken to be the heavily polluted site. The river flows slowly with thick and black water. Sample collection of the only rainy season was possible from this site.

\section{Sample collection}

The present study was conducted during the year 2014. For site 1, sample collection of three seasons (summer, rainy, winter) was made and for sites 2 and 3, sample collection of the only rainy season was performed. In every trip, 30 samples were collected from each site. A different set of materials (e.g., bottles, brush, dropper etc.) were used for each site so that contamination and mixing up of diatom species were avoided. The epilithic forms (present as a slippery coating on stones) were collected using a toothbrush, the epipelic forms (residing on sand/mud at the edge of river bed) were collected using a dropper, and the epiphytic forms (dwelling on the surfaces of other plants like moss) were collected by squeezing aquatic macrophytes. The collections were then preserved in FAA solution. The sampling number, locality site, collection date, method of collection, season and habitats for each collection were labeled. The nature of habitat, water pollution level, and surrounding vegetation were also noted in the field book. The geographical position of each collection site was noted using GPS Garmin e-Trex. Photographs of the locality were captured using Canon Digital Camera. All diatom samples were carried to the Phycological Research Lab, Department of Botany, PG Campus, Biratnagar for further study.

Preliminary screening of samples was done. Permanent slides of diatom were made according to the modified method of PCER, ANSP (1988). Microphotograph of each species was taken using an Olympus CH20i microscope with a camera attached. Diatoms were identified up to species and variety levels following LangeBertalot (2001), Krammer and Lange-Bertalot (1991), Krammer (2002), Mann et al. (2004), Metzeltin et al. (2009), Lange-Bertalot et al. (2011), and Karthick et al. (2013). The collected samples and permanent slides have been deposited in the Phycological Research Lab, Department of Botany, PG Campus, Biratnagar.

\section{RESULTS AND DISCUSSION}

A total of 48 diatom taxa were reported from Bagmati river belonging to 12 families and 25 genera (Rai and Khadka, 2017). Out of which, 42 taxa (87.5\%) were recorded from Mulkharka, 20 taxa (41.66\%) from Gokarna and only 19 taxa $(39.58 \%)$ from Pashupati site throughout all the three seasonal collections. Similarly, diatom size was also variable in three different sites as large sized were restricted to Mulkharka, medium sized were found in Gokarna and small sized were rich in Pashupati site. This decrease in the number of diatom species and size from Mulkharka to Gokarna to Pashupati sites may be due to the increase in pollution level and the decrease in water current in three different sites of the river. Growth and development may be less in highly polluted and nearly stagnant water at Pashupati site, but clean and running water stream of Mulkharka site influence well growth and development of diatoms.

In general, frequently observed diatoms of 
Bagmati River were Achnanthes crenulata, Gomphonema pseudoaugur, Nitzschia linearis, N. palea, Pinnularia cf divergens and Surirella linearis. Second frequent species were Gomphonema gandhii, G. parvulum, Navicula radiosa, $N$. rostellata and Planothidium lanceolatum. Rarely present species were Amphora ovalis, Aulacoseira granulata, Cymbella aspera, C. tumida, Diploneis ovalis, Encyonema ventricosum, Epithemia adnata, E. sorex, Eunotia bidens, E. botuliformis, E. minor, Fragilaria vaucheriae, Frustulia rhomboides var. saxonica, Gomphonema acidoclinatum, Gyrosigma kuetzingii, Meridion circulare var. constrictum, Pinnularia grunowii, Stauroneis gracilis and S. smithii.

Diatom diversity in three different sites (Mulkharka, Gokarna, Pashupati) of Bagmati River in the rainy season

When observed only on rainy season, a total of 35 diatoms were reported from three different sites, out of which a maximum number of diatom taxa were reported from Mulkharka (68.57\%), then followed by Gokarna and Pashupati sites with $57.14 \%$ and 54.28\% taxa, respectively (Fig. 2, Table 1). Diatoms common to all three sites were Achnanthes crenulata, Cymbella turgidula, Gomphonema Gandhii, G. parvulum, $G$. pseudoaugur, Gyrosigma scalproides, Navicula radiosa, Navicula rostellata, Sellaphora capitata and Ulnaria ulna. Diatoms reported only from
Mulkharka site in rainy season were Cocconeis placentula, Diploneis ovalis, Epithemia adnata, Eunotia minor, Frustulia rhomboides var. saxonica, Gyrosigma kuetzingii, Pinnularia microstauron, Planothidium lanceolatum and Surirella linearis. Diatoms viz., Amphora ovalis, Aulacoseira granulata, Cymbella aspera, Encyonema ventricosum, Eunotia bidens, Eunotia botuliformis, Gomphonema acidoclinatum, Gomphonema rhombicum, Meridion circulare var. constrictum, Neidium ampliatum, Stauroneis gracilis, Stauroneis smithii and Surirella splendida were also found only in Mulkharka but during summer and winter seasons. Similarly, diatoms reported only from Gokarna site were Cymbella tumida, Pinnularia grunowii and Surirella angusta and only from Pashupatinath were Epithemia sorex, Fragilaria vaucheriae and Navicula escambia.

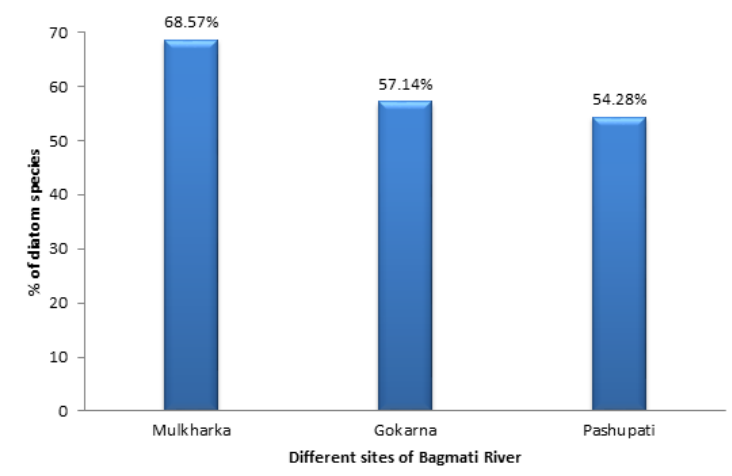

Fig. 2. Presence of diatoms at different sites of Bagmati river in the rainy season.

Table 1. Diatoms diversity at different sites of Bagmati river in the rainy season.

\begin{tabular}{llcc}
\hline \multirow{2}{*}{ SN } & Diatoms & \multicolumn{2}{c}{ Sampling sites in Bagmati river } \\
\cline { 3 - 4 } & & Mulkharka Gokarna & Pashupati \\
\hline 1 & Achnanthes crenulata Grunow & ++++ & + \\
2 & Achnanthes inflate (Kützing) Grunow & + & - \\
3 & Cocconeis placentula Ehrenberg & + & - \\
4 & Cyclotella meneghiniana Kützing & + & - \\
5 & Cymbella tumida (Brébisson) Van Heurck & - & + \\
\end{tabular}


6 Cymbella turgidula Grunow

7 Diatoma hiemale var. mesodon (Ehrenberg) Grunow

8 Diploneis ovalis (Hilse) Cleve

9 Encyonema hustedtii Krammer

10 Epithemia adnata (Kützing) Brébisson

11 Epithemia sorex Kützing

12 Eunotia minor (Kützing) Grunow

13 Fragilaria vaucheriae (Kützing) J.B. Petersen

14 Frustulia rhomboides var. saxonica (Rabenhorst) De Toni

15 Frustulia vulgaris (Thwaites) De Toni

16 Gomphonema gandhii Karthick et Kociolek

17 Gomphonema parvulum (Kützing) Kützing

18 Gomphonema pseudoaugur Lange-Bertalot

19 Gyrosigma kuetzingii (Grunow) Cleve

20 Gyrosigma scalproides (Rabenhorst) Cleve

21 Navicula escambia (R.M. Patrick) Metzeltin et Lange-Bertalot

22 Navicula radiosa Kützing

23 Navicula rhyncocephala Kützing

24 Navicula rostellata Kützing

25 Nitzschia linearis W. Smith

26 Nitzschia palea (Kützing) W. Smith

27 Pinnularia cf divergens W. Smith

28 Pinnularia grunowii Krammer

29 Pinnularia microstauron (Ehrenberg) Cleve

30 Pinnularia viridis (Nitzsch) Ehrenberg

31 Planothidium lanceolatum (Brébisson ex Kützing) Lange-Bertalot +

32 Sellaphora capitata D.G. Mann et S.M. McDonald

33 Surirella angusta Kützing

34 Surirella linearis W. Smith

35 Ulnaria ulna (Nitzsch) Compère

Total diatom taxa

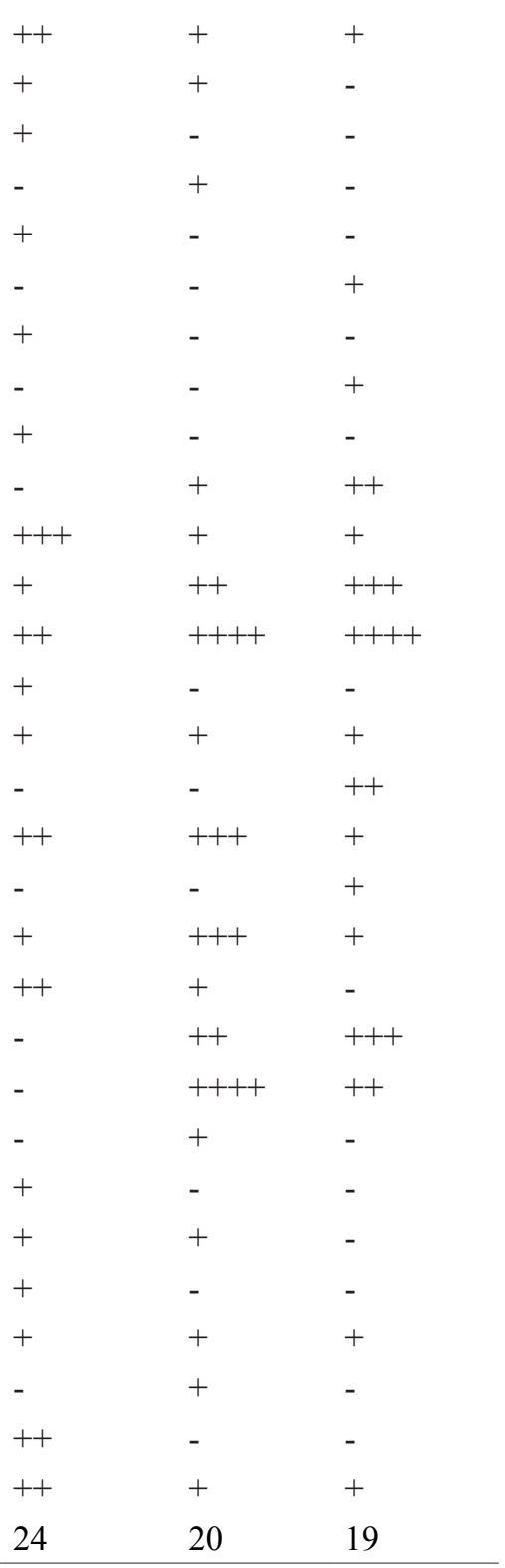

++++ Dominant, +++ Frequent, ++ Common, + Occasional, - absent

Diatom diversity in different seasons at Mulkharka site, Bagmati River.

Diatom flora during summer, winter and rainy seasons observed at Mulkharka site showed that Achnanthes crenulata, Nitzschia linearis and Surirella linearis were dominant taxa throughout all three seasons. Out of 42 taxa, the maximum number of diatoms were reported during summer
(92.85\%) followed by rainy $(57.14 \%)$ and least during winter $(23.80 \%)$ (Fig. 3, Table 2). This variation in the number of taxa may be due to warm temperature that influences the growth and development during summer season. 


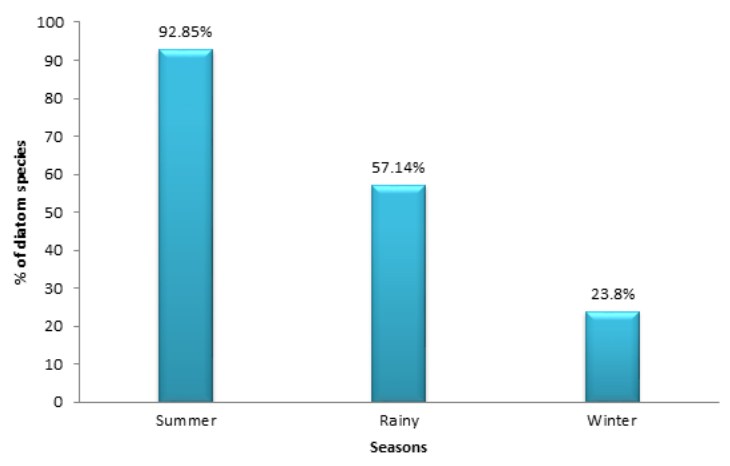

Fig. 3. Presence of diatoms in different seasons at Mulkharka, Bagmati river

Diatoms occurred in all three seasons were Achnanthes crenulata, Diatoma hiemale var. mesodon, Gomphonema gandhii, G. parvulum, Navicula radiosa, Nitzschia linearis, Pinnularia viridis, Planothidium lanceolatum, Surirella linearis and Ulnaria ulna. Diatoms reported only during summer season were Amphora ovalis, Aulacoseira granulata, Cyclotella meneghiniana, Cymbella aspera, Encyonema hustedtii, E. ventricosum, Epithemia adnata, Eunotia bidens, E. botuliformis, Frustulia vulgaris, Gomphonema acidoclinatum, G. rhombicum, Gyrosigma kuetzingii, $G$. scalproides, Meridion circulare var. constrictum, Navicula rhyncocephala, $N$. rostellata, Neidium ampliatum, Nitzschia palea, Pinnularia cf divergens, Stauroneis gracilis, S. smithii and Surirella splendida. Similarly, diatoms reported only during the rainy season were Achnanthes inflata, Diploneis ovalis and Frustulia rhomboides var. saxonica. All diatoms reported during winter were also observed during other seasons.

\section{Diatom diversity on different habitats of Mulkharka site, Bagmati River}

Diatom diversity studied on different habitats at Mulkharka site showed that maximum taxa were epilithic (attached on stone) (35) followed by epipelic (attached on mud and sand) (15) and epiphytic (attached on moss plant) (13) (Fig. 4, Table 2). Diatoms present in all three habitats were Achnanthes crenulata, Diatoma hiemale var. mesodon, Navicula radiosa, Nitzschia linearis, Planothidium lanceolatum, Surirella linearis and Ulnaria ulna. The following diatoms were inhabitated only on stones-Aulacoseira granulata, Cocconeis placentula, Cyclotella meneghiniana, Cymbella turgidula, Encyonema hustedtii, E. ventricosum, Epithemia adnata, Eunotia bidens, E. botuliformis, E. minor, Gomphonema acidoclinatum, G. pseudoaugur, Gyrosigma kuetzingii, G. scalproides, Navicula rostellata, Pinnularia cf divergens, $P$. microstauron, Stauroneis gracilis and S. smithii. Diatoms inhabited only on sand and mud were Amphora ovalis and Meridion circulare var. constrictum and only on moss plants were Cymbella aspera and Navicula rhyncocephala.

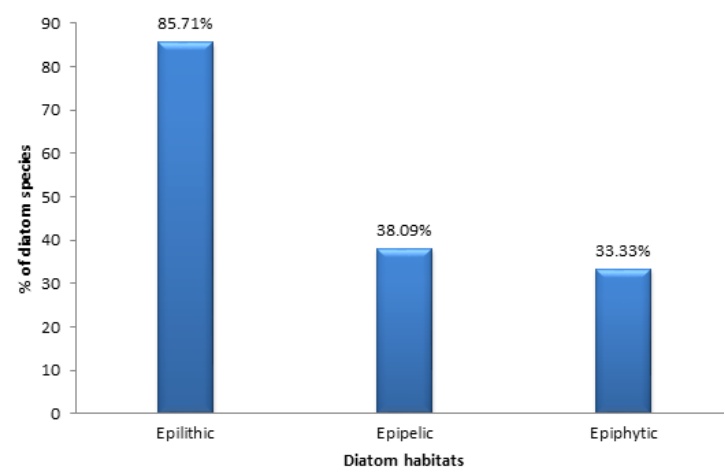

Fig. 4. Presence of diatoms on different habitats at Mulkharka, Bagmati river. 
Table 2. Diatom diversity in different seasons and habitats at Mulkharka site, Bagmati river.

\begin{tabular}{|c|c|c|c|c|c|c|c|}
\hline \multirow{2}{*}{ SN } & \multirow{2}{*}{ Diatoms } & \multicolumn{3}{|c|}{ Seasons } & \multicolumn{3}{|c|}{ Habitats } \\
\hline & & Summer & Rainy & Winter & Epilithic & Epipelic & Epiphytic \\
\hline 1 & Achnanthes crenulata Grunow & ++++ & ++++ & ++++ & ++++ & + & ++++ \\
\hline 2 & Achnanthes inflate (Kützing) Grunow & - & + & - & - & - & + \\
\hline 3 & Amphora ovalis (Kützing) Kützing & + & - & - & - & + & - \\
\hline 4 & Aulacoseira granulata & + & - & - & + & - & - \\
\hline 5 & Cocconeis placentula Ehrenberg & + & + & - & + & - & - \\
\hline 6 & Cyclotella meneghiniana Kützing & ++ & + & - & ++ & - & - \\
\hline 7 & Cymbella aspera (Ehrenberg) Simonsen & + & - & - & - & - & + \\
\hline 8 & Cymbella turgidula Grunow & + & ++ & - & + & - & - \\
\hline 9 & Diatoma hiemale var. mesodon (Ehrenberg) Grunow & ++ & + & ++ & ++ & ++ & + \\
\hline 10 & Diploneis ovalis (Hilse) Cleve & - & + & - & - & + & - \\
\hline 11 & Encyonema hustedtii Krammer & + & - & - & + & - & - \\
\hline 12 & Encyonema ventricosum (C. Agardh) Grunow & + & - & - & + & - & - \\
\hline 13 & Epithemia adnata (Kützing) Brébisson & + & + & - & + & - & - \\
\hline 14 & Eunotia bidens Ehrenberg & + & - & - & + & - & - \\
\hline 15 & Eunotia botuliformis G.-R. Wang & + & - & - & + & - & - \\
\hline 16 & Eunotia minor (Kützing) Grunow & + & + & - & + & - & - \\
\hline 17 & Frustulia rhomboides var. saxonica (Rabenhorst) De Toni & - & + & - & + & - & - \\
\hline 18 & Frustulia vulgaris (Thwaites) De Toni & + & - & - & + & + & - \\
\hline 19 & Gomphonema acidoclinatum Lange-Bertalot et Reichardt & + & - & - & + & - & - \\
\hline 20 & Gomphonema gandhii Karthick et Kociolek & + & +++ & +++ & +++ & + & - \\
\hline 21 & Gomphonema parvulum (Kützing) Kützing & ++ & + & + & + & - & ++ \\
\hline 22 & Gomphonema pseudoaugur Lange-Bertalot & +++ & ++ & - & +++ & - & - \\
\hline 23 & Gomphonema rhombicum Fricke & + & - & - & ++ & + & + \\
\hline 24 & Gyrosigma kuetzingii (Grunow) Cleve & + & + & - & + & - & - \\
\hline 25 & Gyrosigma scalproides (Rabenhorst) Cleve & + & + & - & + & - & - \\
\hline 26 & Meridion circulare var. constrictum (Ralfs) Van Heurck & + & - & - & - & + & - \\
\hline 27 & Navicula radiosa Kützing & +++ & ++ & ++ & +++ & +++ & ++ \\
\hline 28 & Navicula rhyncocephala Kützing & + & - & - & - & - & + \\
\hline 29 & Navicula rostellata Kützing & +++ & + & - & +++ & - & - \\
\hline 30 & Neidium ampliatum (Ehrenberg) Krammer & + & - & - & + & - & + \\
\hline 31 & Nitzschia linearis W. Smith & ++++ & ++ & ++++ & +++ & ++++ & ++++ \\
\hline 32 & Nitzschia palea (Kützing) W. Smith & +++ & - & - & +++ & - & ++ \\
\hline 33 & Pinnularia cf divergens W. Smith & ++++ & - & - & ++++ & - & - \\
\hline 34 & Pinnularia microstauron (Ehrenberg) Cleve & + & + & - & + & - & - \\
\hline 35 & Pinnularia viridis (Nitzsch) Ehrenberg & + & + & + & + & + & - \\
\hline 36 & Planothidium lanceolatum (Brébisson ex Kützing) Lange-Bertalot & +++ & + & ++ & ++ & ++ & +++ \\
\hline 37 & Sellaphora capitata D.G. Mann et S.M. McDonald & ++ & + & - & ++ & + & - \\
\hline 38 & Stauroneis gracilis Ehrenberg & + & - & - & + & - & - \\
\hline 39 & Stauroneis smithii Grunow & + & - & - & + & - & - \\
\hline 40 & Surirella linearis W. Smith & ++++ & ++ & ++++ & ++++ & ++++ & ++++ \\
\hline & Surirella splendid (Ehrenberg) Kützing & + & - & - & + & + & - \\
\hline 42 & Ulnaria ulna (Nitzsch) Compère & ++ & ++ & ++ & ++ & + & + \\
\hline Tot & al diatom taxa & 39 & 24 & 10 & 36 & 16 & 14 \\
\hline
\end{tabular}

++++ Dominant, +++ Frequent, ++ Common, + Occasional, - absent 
The dominant diatoms in epilithic habitat were Achnanthes crenulata, Pinnularia of divergens and Surirella linearis. Similarly, dominant taxa in epipelic habitat were Nitzschia linearis and Surirella linearis and in epiphytic habitat were Achnanthes crenulata, Nitzschia linearis and Surirella linearis.

In general, dominant diatom taxa of Bagmati river were Achnanthes crenulata, Gomphonema pseudoaugur, Nitzschia linearis, N. palea, Pinnularia of divergens and Surirella linearis and rarely present species were Amphora ovalis, Aulacoseira granulata, Cymbella aspera, C. tumida, Diploneis ovalis, Encyonema ventricosum, Epithemia adnata, E. sorex, Eunotia bidens, E. botuliformis, E. minor, Fragilaria vaucheriae. The poor representations throughout the study period were of following genera viz., Amphora, Aulacoseira, Cocconeis, Cyclotella, Diatoma, Diploneis, Fragilaria, Meridion, Neidium, Planothidium, Sellaphora and Ulnaria. These were represented by single taxa.

\section{CONCLUSIONS}

A total of 48 diatom taxa belonging to 25 genera and 12 families were enumerated in three seasons from three different sites of Bagmati River. The maximum number of diatom taxa $(87.5 \%)$ was found in Mulkharka and minimum number (39.58\%) was found in Pashupati sites. Thus, Mulkharka site favoured the luxuriant growth of diatoms with rich diversity. There were 10 common diatom taxa found in all three sites. Nine taxa occurred at Mulkharka only, 4 each occurred at Gokarna and Pashupati sites only. At Mulkharka, the maximum number of taxa was reported during summer $(92.85 \%)$ and least during winter (23.8\%). Diatom diversity studied on different habitats at Mulkharka showed that the maximum taxa were epilithic $(85.71 \%)$ followed by epipelic $(38.09 \%)$ and epiphytic (33.33\%). Largest sized diatoms were observed in Mulkharka and smallest sized were observed in Pashupati sites. Further extensive studies are required for a better documentation and understanding of diatoms flora of Bagmati River.

\section{ACKNOWLEDGEMENT}

We are thankful to the Head, Department of Botany, Post Graduate Campus, Tribhuvan University, Biratnagar for laboratory facilities.

\section{REFERENCES}

Aryal, S. and P. Lacoul (1996). Water quality and diversity of diatoms in Punyamati river, Nepal. Ecoprint 3(1): 45-49.

Baral, S.R. (1999). Algae of Nepal. In: Nepal Nature's Paradise, Majupuria, T.C. and Kumar, R. (eds.), Gwalior, India. pp. 655681.

Cantonati, M., G.Corradini, I. Jüttner, and E.J. Cox (2001). Diatom assemblages in high mountain streams of the Alps and the Himalaya. Nova Hedwigia 123: 37-61.

Carter, N. (1926). Fresh water algae from India. Records bot. surv. India 9(4): 263-302.

Grethe, R.H., E.S.Erik, A.S. Karen, and T. Karl (1996). Marine diatoms. In: Identifying Marine Diatoms and Dinoflagellates, Carmelo R. Tomas (ed.), Academic Press. $385 p$.

Habib, I. (1997). Algal flora from Mahendranagar, Nepal. J. Econ. and Taxon. Bot. (India) 21(1): 19-26.

Hickel, B. (1973). Phytoplanktons in two ponds in Kathmandu valley, Nepal. Int. Rev. ges Hydrobiol. 58(6): 835-842

Hirano, M. (1955). Fresh water algae. In: Fauna and Flora of Nepal Himalaya, Kihara, $\mathrm{H}$. (ed.), Fauna and Flora Research Society, Kyoto University, Kyoto, Japan. pp. 5-42. Hirano, M. (1963). Fresh water algae from the 
Nepal Himalaya, collected by a member of the Japanese Climbing Expedition. Contr. Biol. Lab., Kyoto University, Japan. 16: 1-23.

Hirano, M. (1969). Freshwater Algae from Rangtang Himal, Nepal Himalaya. Contribution from the Biological Laboratory, Kyoto University, Japan. 22: $1-42$.

Hirano, M. (1984). Fresh water algae from East Nepal. Study report of Baika Junior College 32: 197-215.

Jüttner, I., J. Chimonides, and E.J. Cox (2011). Morphology, ecology and biogeography of diatom species related to Achnanthidium pyrenaicum (Hustedt) Kobayasi (Bacillariophyceae) in streams of the Indian and Nepalese Himalaya. Algological Studies 136/137: 45-76. DOI: 10.1127/18641318/2011/0136-0045

Jüttner, I., K. Krammer, B. Van de Vijver, A.Tuji, B. Simkhada, S. Gurung, S.Sharma, C. Sharma, and E.J. Cox (2010). Oricymba (Cymbellales, Bacillariophyceae), a new cymbelloid genus and three new species from the Nepalese Himalaya. Phycologia 49(5): 407-423. DOI: 10.2216/09-77.1

Jüttner, I., H. Rothfritz, and S.J. Ormerod (1996). Diatoms as indicators of river quality in the Nepalese middle hills with consideration of the effects of habitat-specific sampling. Freshwater Biology 36: 475-486.

Jüttner, I., H. Rothfritz, S.J. Ormerod, P.J. Chimonides, E.J. Cox (2003). Diatoms as indicators of stream quality in the Kathmandu valley and middle hills of Nepal and India. Freshwater Biology 48: 20652084.

Karthick, B., P.B. Hamilton, and J.P. Kociolek (2013). An illustrated guide to common diatoms of Peninsular India. Gubbi Labs,
Gubbi. 206p.

Krammer, K. (2002). Cymbella. In: Diatoms of Europe, diatoms of the European inland waters and comparable habitats, LangeBertalot, H. (ed.), A.R.G. Gantner Verlag K.G. 3: 1-584.

Krammer, K. and H. Lange-Bertalot (1991). Bacillariophyceae 4. Teil: Achnanthaceae, Kritische Erganzungen zu Navicula (Lineolatae) und Gomphonema Gesamt literature verzeichnis Teil 1-4. In: Suesswasserflora von Mitteleuropa, Ettl, H. et al. (eds.), VEB Gustav Fisher Verlag, Jena 2(4): 1-437, 88 pls., 2048 figs.

Krstić, S.S., I. Obreht, W. Zech, Z. Svirčev, S.B. Marković (2012). Late Quaternary environmental changes in Helambu Himal, Central Nepal, recorded in the diatom flora assemblage composition and geochemistry of Lake Panch Pokhari. J. Paleolimnol 47: 113-24. DOI 10.1007/s10933-011-9563-4

Krstić, S.S., A. Pavlov, Z. Levkov, and I. Jüttner (2013). New Eunotia taxa in core samples from Lake Panch Pokhari in the Nepalese Himalaya. Diatom Research 28(2): 203217. DOI:10.1080/0269249X.2013.782343 Lange-Bertalot, H. (2001). Navicula sensu stricto, 10 genera seperated from Navicula sensu lato, Frustulia. In: Diatoms of Europe, diatoms of the European inland waters and comparable habitats, Lange-Bertalot, $\mathrm{H}$. (ed.), A.R.G. Gantner Verlag K.G. 2: 1-526. Lange-Bertalot, H., M. Bak, A.Witkowski, and N. Tagliaventi (2011). Eunotia and some related genera. In: Diatoms of Europe. Diatoms of the European inland water and comparable habitats, Lange-Bertalot, $\mathrm{H}$. (ed.), A.R.G. Gantner Verlag K.G. 6: 747, 237 plates, 5053 figs.

Mann, D.G., S.M. McDonald, M.M. Bayer, S.J.M. Droop, V.A. Chepurnov, R.E. Loke, 
A. Ciobanu, and J.M.H. du Buf (2004). The Sellaphora pupula species complex (Bacillariophyceae): morphometric analysis, ultrastructure and mating data provide evidence for five new species. Phycologia 43(4): 459-482, 52 figs., 4 tables.

Metzeltin, D., H. Lange-Bertalot, and S. Nergui (2009). Diatoms in Mongolia. In: Iconographia Diatomologica. Annotated Diatom Micrographs, vol. 20, LangeBertalot, H. (ed.), A.R.G. Gantner Verlag K.G. 20: 3-686.

Nakanishi, M. (1986). Limnological study in Phewa, Begnas and Rupa lakes. In: Studies on distribution, adaptation and evolution of microorganisms in Nepal Himalayas, $2^{\text {nd }}$ report, Ishida, $\mathrm{Y}$ (ed.), Ministry of Education, Science and Culture, Kyoto, Japan. pp. 3-13.

PCER, ANSP (1988). Diatom cleaning by nitric acid digestion. Protocol no. P-1302. Patrick Center for Environmental Research, Academy of Natural Sciences of Philadelphia. http://diatom. acnatsci.org/ nawqa/pdfs/

Rai, S.K. and S. Khadka (2017). Diatoms of Bagmati River, Kathmandu, Nepal. Nepalese J. of Biosciences 17(1): 1-25.
Shrestha, B. and J.D. Manandhar (1983). Contribution to the algal flora of Kathmandu valley. J. Inst. Sci. Tech. (Nepal) 6: 1-6.

Simkhada, B. and I. Jüttner (2006). Diatoms in ponds and small lakes of the Kathmandu valley, Nepal- relationships with chemical and habitat characteristics. Arch. Hydrobiol. 166(1): 41-65. DOI: 10.1127/00039136/2006/0166-0041

Suxena, M.R. and V.Venkateswarlu(1968). Algae of the Cho Oyu (E. Himalaya) Expedition-I. Bacillariophyceae. Hydrobiologia 32: 1-26. Van De Vijver, B., I. Jüttner, S. Gurung, C. Sharma, S. Sharma, M. De Haan, and E.J. Cox (2011). The genus cymbopleura (Cymbellales, Bacillariophyta) from high altitude freshwater habitats, Everest National Park, Nepal, with the description of two new species. Fottea 11(2): 245-269.

Vyverman, W., E. Verleyen, A. Wilmotte, D.A. Hodgson, A. Willems, K. Peeters, B. Van de Vijver, A. de Wever, F. Leliaert, and K. Sabbess (2010). Evidence for widespread endemism among Antarctic microorganisms. Polar Science 4: 10-11.

Received 17 Jan 2018

Revised accepted 21 Sept 2018 